\title{
AMS-14C CHRONOLOGY OF A LACUSTRINE SEQUENCE FROM LAKE LANGANO (MAIN ETHIOPIAN RIFT): CORRECTION AND VALIDATION STEPS IN RELATION WITH VOLCANISM, LAKE WATER AND CARBON BALANCES
}

\author{
Elisabeth Gibert ${ }^{1,2} \bullet$ Yves Travi $^{3} \bullet$ Marc Massault $^{1} \bullet$ Jean-Jacques Tiercelin ${ }^{4} \bullet$ Tesfaye $^{\text {Chernet }}{ }^{3}$ \\ ABSTRACT. Located in the Ziway-Shala Basin of the Main Ethiopian Rift, Lake Langano is part of an asymmetric half-gra- \\ ben, defined by a series of north-northeast-trending faults in the tectonically active zone of the rift. A 15-m deep succession \\ of organic homogeneous muds, silts, bioclastic sands, and pyroclastic layers was cored in 1994. The definition of a certified \\ radiocarbon chronology on these deposits required the indispensable establishment of modern hydrological and geochemical \\ balances. The isotopic contents of the total dissolved inorganic carbon (TDIC) of surface water clearly show the influence of \\ a deep $\mathrm{CO}_{2}$ rising along the main fault crossing the lake basin. The $5.8 \mathrm{pMC}$ disequilibrium existing in 1994 with the atmo- \\ sphere likely produces the aging of authigenic materials developing at the lake surface. However, with a mean residence time \\ of $\sim 15$ years, this apparent ${ }^{14} \mathrm{C}$ aging of Lake Langano water still integrates the ${ }^{14} \mathrm{C}$ produced by the nuclear tests in the $1960 \mathrm{~s}$. \\ Reconstructing the natural ${ }^{14} \mathrm{C}$ activity of the lake TDIC allows for the quantification of the deep $\mathrm{CO}_{2}$ influence, and for the \\ correction of AMS- ${ }^{14} \mathrm{C}$ datings performed along the core. The correction of the AMS $-{ }^{14} \mathrm{C}$ chronology defined on Lake Lan- \\ gano allows for a better understanding of paleohydrological changes at a regional scale for at least the last 12,700 cal BP.
}

\section{INTRODUCTION}

We present here part of the geochemical and isotopic investigations of lake water and sediments performed on Lake Langano that belongs to the Ziway-Shala Basin, Main Ethiopian Rift (Figure 1). This study was conducted under the French-Ethiopian Project ERICA ("Environmental Research for Intertropical Climate in Africa") funded since 1994 by both specific research programs of INSUCNRS (PNEDC/DYTEC/VARIENTE), the French-Ethiopian Cooperative Program in Earth Sciences (INSU-CNRS), the Ministry of Foreign Affairs (France), and the Department of Geology and Geophysics, University of Addis-Ababa (Ethiopia). This paper focuses on performing and correcting the accelerator mass spectrometry (AMS)-radiocarbon datings on authigenic materials taken from the LL-III sedimentary sequence collected in the north-eastern part of Lake Langano in 1994 (Figure 1), with the aim of:

1. defining more precisely the lake hydrological and geochemical balances in a very active geodynamic/geothermic context, i.e., taking into account deep gases and diagenetical processes influences,

2. validating the AMS- ${ }^{14} \mathrm{C}$ corrections and chronology via the application of two successive geochemical correction models, and

3. trying to contribute to the reconstruction of paleoenvironmental evolution at a regional scale by comparing sedimentary rates of depositional sequences with paleoenvironmental phases already described in the Ziway-Shala Basin (Gasse and Street 1978; Street 1981; Bonnefille et al. 1986; Gibert et al. 1999).

Because ${ }^{14} \mathrm{C}$ excess has been produced in the atmosphere due to nuclear weapons testing in the mid 1950s and integrated in the biosphere, most of the studies conducted focused on the measurements of atmospheric ${ }^{14} \mathrm{C}$ activity as an accurate indicator of $\mathrm{CO}_{2}$ exchanges between the different carbon

${ }^{1}$ FRE 2566-ORSAYTERRE, CNRS-UPS, Equipe «Hydrologie, Paléohydrologie et Paléoenvironnement», Université ParisSud, Bâtiment 504, F-91405 Orsay cedex, France

${ }^{2}$ Corresponding author. Email: egibert@ geol.u-psud.fr.

${ }^{3}$ Laboratoire d'Hydrogéologie, Département de Géologie, Faculté des Sciences d'Avignon, 33 rue Louis Pasteur, F-84000 Avignon, France

${ }^{4}$ UMR 6538 "Domaines Océaniques", Institut Universitaire Européen de la Mer, Place Nicolas Copernic, F-29280 Plouzané, France 

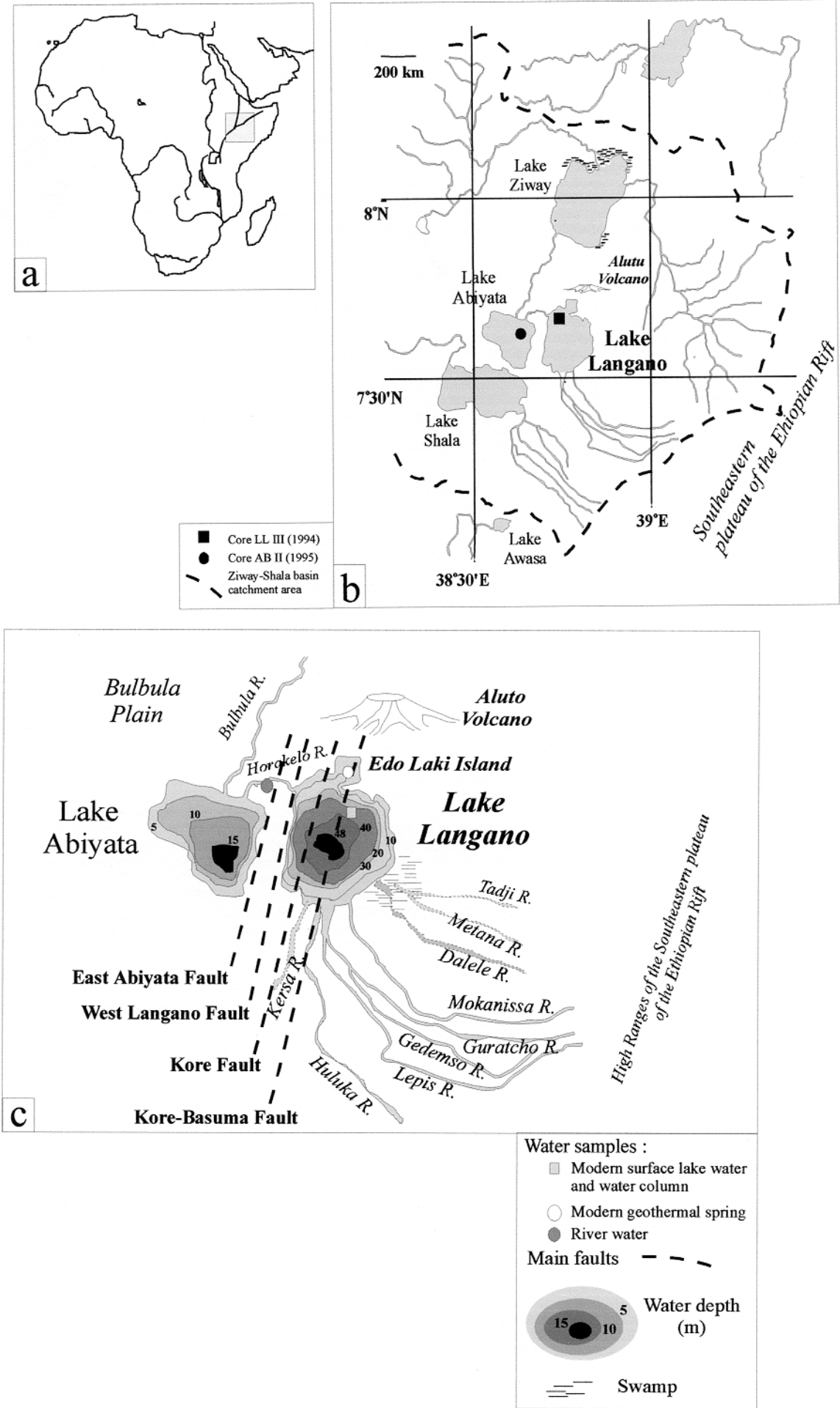

Figure 1 Parts a and b: location map of the Ziway-Shala basin and of Lake Langano (East Ethiopian Rift); part c: Bathymetry of Lakes Abiyata and Langano, location of water samples and of Lake Langano Core LL-III (see text and Figure 5 for description). 
Table 1a (top) Measured AMS- ${ }^{14} \mathrm{C}$ activities and associated $\delta^{13} \mathrm{C}$ values of sediments from Lake Langano Core LL-III. Table $1 \mathrm{~b}$ (bottom) AMS- ${ }^{14} \mathrm{C}$ datings of sediments from Lake Langano Core LL-III. Key: A-Measured ${ }^{14} \mathrm{C}$ ages; B- ${ }^{14} \mathrm{C}$ ages corrected from the TDIC aging, considering a mean residence time of $15 \mathrm{yr} ; \mathrm{C}-{ }^{14} \mathrm{C}$ ages of column $\mathrm{B}$ corrected from post-sedimentary recrystallization; D—calibration of ${ }^{14} \mathrm{C}$ ages of columns A to $\mathrm{C}$; E- ${ }^{14} \mathrm{C}$ ages corrected from the TDIC aging, considering a mean residence time of $20 \mathrm{yr}$; F- ${ }^{14} \mathrm{C}$ ages of column E corrected from post-sedimentary recrystallization; $\mathrm{G}-$ calibration of ${ }^{14} \mathrm{C}$ ages of columns $\mathrm{A}, \mathrm{E}$, and $\mathrm{F}$.

\begin{tabular}{cccccc}
\hline $\begin{array}{c}\text { Depth } \\
(\mathrm{cm})\end{array}$ & Type & $\begin{array}{c}\text { Analyse } \mathrm{Nr} \\
\text { (Orsay) }\end{array}$ & $\begin{array}{c}{ }^{14} \mathrm{C} \text { Activity } \\
\text { (pMC) }\end{array}$ & $\begin{array}{c}\text { Measured } \\
{ }^{14} \mathrm{C} \text { Age (yr B.P.) }\end{array}$ & $\begin{array}{c}\delta^{13} \mathrm{C} \\
(\% \text { vs PDB })\end{array}$ \\
\hline 121.5 & Charcoal & H1495 & $57.2 \pm 0.8$ & $4490 \pm 70$ & -15.88 \\
246.0 & TOM & H1492 & $49.4 \pm 1.3$ & $5670 \pm 100$ & - \\
412.9 & Charcoal & H1420 & $47.5 \pm 0.9$ & $5980 \pm 80$ & -18.17 \\
645.6 & TOM & H1421 & $40.4 \pm 1.0$ & $7280 \pm 80$ & -25.16 \\
817.1 & Charcoal & H1217 & $30.8 \pm 0.4$ & $9460 \pm 100$ & -24.60 \\
958.0 & Charcoal & H1220 & $30.3 \pm 0.4$ & $9590 \pm 100$ & -20.98 \\
970.3 & Charcoal & H1369 & $30.1 \pm 0.3$ & $9640 \pm 80$ & - \\
1048.0 & Shell & H1189 & $21.7 \pm 0.3$ & $12270 \pm 100$ & - \\
1185.0 & Shell & H1190 & $24.3 \pm 0.3$ & $11360 \pm 110$ & - \\
\hline
\end{tabular}

Table 1a

TOM : Total Organic Matter; Error bars correspond to 1 sigma $(1 \sigma)$ deviation. Sampling date : November 1995.

Analytical uncertainties of ${ }^{13} \mathrm{C}$ measurements on TOM and biogenic carbonates are 0.05 and $0.02 \%$ vs PDB respectively.

Table $1 \mathbf{b}$

$\mathbf{A}$

B

$\mathbf{C}$

D

$\mathbf{E}$

$\mathbf{F}$

$\mathbf{G}$

\begin{tabular}{|c|c|c|c|c|c|c|c|c|}
\hline $\begin{array}{l}\text { Depth } \\
\text { (cm) }\end{array}$ & $\begin{array}{l}{ }^{14} \mathrm{C} \text { Activity } \\
\text { (pMC) }\end{array}$ & $\begin{array}{l}\text { Measured } \\
{ }^{14} \mathrm{C} \text { Age } \\
\text { (yr B.P.) }\end{array}$ & $\begin{array}{l}{ }^{14} \text { C Age (yr B.P.) } \\
\text { Corrected from } \\
\text { TDIC ageing } \\
\left({ }^{* T R}=15 \text { yr) }\right.\end{array}$ & $\begin{array}{c}{ }^{14} \text { C Age (yr B.P.) } \\
\text { Corrected from } \\
\text { TDIC }(* T R=15 y r) \\
\text { and } \\
\text { recrystallization }\end{array}$ & $\begin{array}{c}\text { Calibrated } \\
{ }^{14} \mathrm{CAges}{ }^{(*)} \\
\text { (cal. yr B.P.) } \\
\left({ }^{* T R}=15 \text { yr) }\right.\end{array}$ & $\begin{array}{l}{ }^{14} \mathrm{C} \text { Age (yr B.P.) } \\
\text { Corrected from } \\
\text { TDIC ageing } \\
\left({ }^{* *} \mathrm{TR}=20 \mathrm{yr}\right)\end{array}$ & $\begin{array}{l}{ }^{14} \mathrm{C} \text { Age (yr B.P.) } \\
\text { Corrected from } \\
\text { TDIC }(* * \text { TR }=20 \mathrm{yr}) \\
\text { and } \\
\text { recrystallization }\end{array}$ & $\begin{array}{c}\text { Calibrated } \\
{ }^{14} \text { C Ages }{ }^{(*)} \\
\text { (cal. yr B.P.) } \\
\left({ }^{* *} \mathrm{TR}=20 \text { yr) }\right.\end{array}$ \\
\hline 121.5 & $57.2 \pm 0.8$ & $4490 \pm 70$ & & & $5120(5315 / 4960)$ & & & $5120(5315 / 4960))$ \\
\hline 246.0 & $49.4 \pm 1.3$ & $5670 \pm 100$ & 4880 & & $5600(5670 / 5590)$ & 4690 & & $5385(5585 / 5310)$ \\
\hline 412.9 & $47.5 \pm 0.9$ & $5980 \pm 80$ & & & $6800(6895 / 6685)$ & & & $6800(6895 / 6685)$ \\
\hline 958.0 & $30.3 \pm 0.4$ & $9590 \pm 100$ & & & $10870(11165 / 10700)$ & & & $10870(11165 / 1070$ \\
\hline 970.3 & $30.1 \pm 0.3$ & $9640 \pm 80$ & & & $11110(11170 / 10760)$ & & & $11110(11170 / 1076$ \\
\hline 1048.0 & $21.7 \pm 0.3$ & $12270 \pm 100$ & 11560 & 9990 & $11400(11685 / 11235)$ & 11310 & 9710 & 11165 (11200/10870) \\
\hline 1185.0 & $24.3 \pm 0.3$ & $11360 \pm 110$ & 10580 & & $12725(12875 / 12355)$ & 10390 & & 12330 (12770//11955) \\
\hline
\end{tabular}

*, with $\Delta$ equal to 9.32 , and $* *$, with $\Delta$ equal to $12.42 \mathrm{pMC}$ (see text for details).

${ }^{(*)}{ }^{4} \mathrm{C}$ calibration method: CALIB 4.0 program, Stuiver et al. 1998a. Radiocarbon $40(3): 1041-83$. 
reservoirs such as the different compartments of the atmosphere, the ocean, and the biosphere at a global scale. More recently, highly accurate studies have been performed on speleothems, considering 2- or 3-black box models for the reconstruction of e.g. vegetation conditions and $\mathrm{CO}_{2}$ partial pressure in caves (Genty and Massault 1997, 1999). However, little was performed on the integration and recycling of this nuclear-induced ${ }^{14} \mathrm{C}$ in lakes, in relation with the lake water balance used as an indispensable reference system, for past environmental reconstructions in continental domains.

Overimposed to the recent history of ${ }^{14} \mathrm{C}$ at a global scale, the understanding and modeling of regional/local production and dissolution of deep gases in surface water bodies (such as $\mathrm{CO}_{2}$ or $\mathrm{CH}_{4}$ linked to underwater geothermal springs) are required in areas where global paleoenvironmental changes can be hidden by local hydrological and hydrogeochemical fluctuations linked to volcanic and/or tectonic evolution of the region. This is of high importance because the main problem encountered for paleoclimatic reconstructions at a global scale from cored lacustrine sequences remains the establishment of reliable ${ }^{14} \mathrm{C}$ time-scales especially in regions closely related to the monsoon evolution such as East Africa or Tibet (e.g. Gasse et al. 1990; Fontes and Gasse 1991; Fontes et al. 1993, 1996; Colman et al. 1996; Johnson 1996; Geyh et al. 1998; Gibert et al. 1999; Gasse 2000).

\section{BACKGROUND}

\section{Climatological and Geological and Settings}

The four lakes Ziway, Langano, Abiyata, and Shala belong to a 100-km-long and 40-km-wide, northnortheast-south-southwest trending faulted and caldera-bearing system located in the axial zone of the Main Ethiopian Rift between $7^{\circ}$ and $8^{\circ} 30^{\prime} \mathrm{N}$ latitude (Figure 1). This complex basin is bound to the east by the Southeastern Plateau including the Arussi-Bale Massif, and in to west by the Ethiopian Shewan Plateau. Fluvio-lacustrine sediments (silts, clays, diatomites) interbedded with volcanic/volcanoclastic products form the 600-m-thick infill of the basin (Le Turdu et al. 1999).

The regional climate of the Ziway-Shala area is tropical monsoonal with mean annual precipitation and mean annual temperatures varying respectively from $1180 \mathrm{~mm}$ and $16.3{ }^{\circ} \mathrm{C}$ on the highlands (Addis-Ababa station; Figure 1a; WMO/IAEA Network 1998; Rozanski et al. 1996), to $600 \mathrm{~mm}$ and $25.0^{\circ} \mathrm{C}$ on the drier part of the lowlands around the lakes (Chernet 1982). The pluviometric regime is driven by the yearly oscillation of the Inter-Tropical Convergence Zone (ITCZ), which determines a warm, wet summer (maximum rainfall from June to September), and a dry, cold, and windy winter. However, the study area is located south of the Addis-Ababa station, and is thus comprised between the unimodal (e.g. Addis-Ababa), and the bimodal annual cycles of rainfall (with a second, short rainfall season in March-April; Chernet 1998).

Lake Langano $\left(7^{\circ} 40^{\prime} \mathrm{N}, 38^{\circ} 50^{\prime} \mathrm{E} ; 1582 \mathrm{~m}\right.$ asl) occupies a $20-\mathrm{km}$-long, asymmetric half-graben in a central basin (48-m maximum water depth) and western littoral plateau (34-m maximum water depth), both delineated by a set of three north-northeast-trending faults, i.e., the West Langano, Kore and Kore-Basuma Faults (namely WLF, KF, and KBF; Figures 1c and 2). Unlike neighboring Lake Abiyata, which occupies a rather stable depression (Gibert et al. 1999), Lake Langano basin is still tectonically active, as indicated by faulted modern sediments and natural gas bubbles of geothermal origin reaching the lake surface above the KBF (Le Turdu et al. 1999; Figure 1c).

Furthermore, degassing has been suspected to the north along the KBF, as well as along the WLF (Figure 2), and evidenced through isotopic measurements on groundwater and soil gases (Tables 2 and 4). Knowing that carbonated gas such as $\mathrm{CO}_{2}$ or $\mathrm{CH}_{4}$ may alter the ${ }^{14} \mathrm{C}-{ }^{13} \mathrm{C}$ system via apparent water aging, analyses of the ${ }^{13} \mathrm{C}$ signature of soil $\mathrm{CO}_{2}$ have been performed around Lake Langano. 


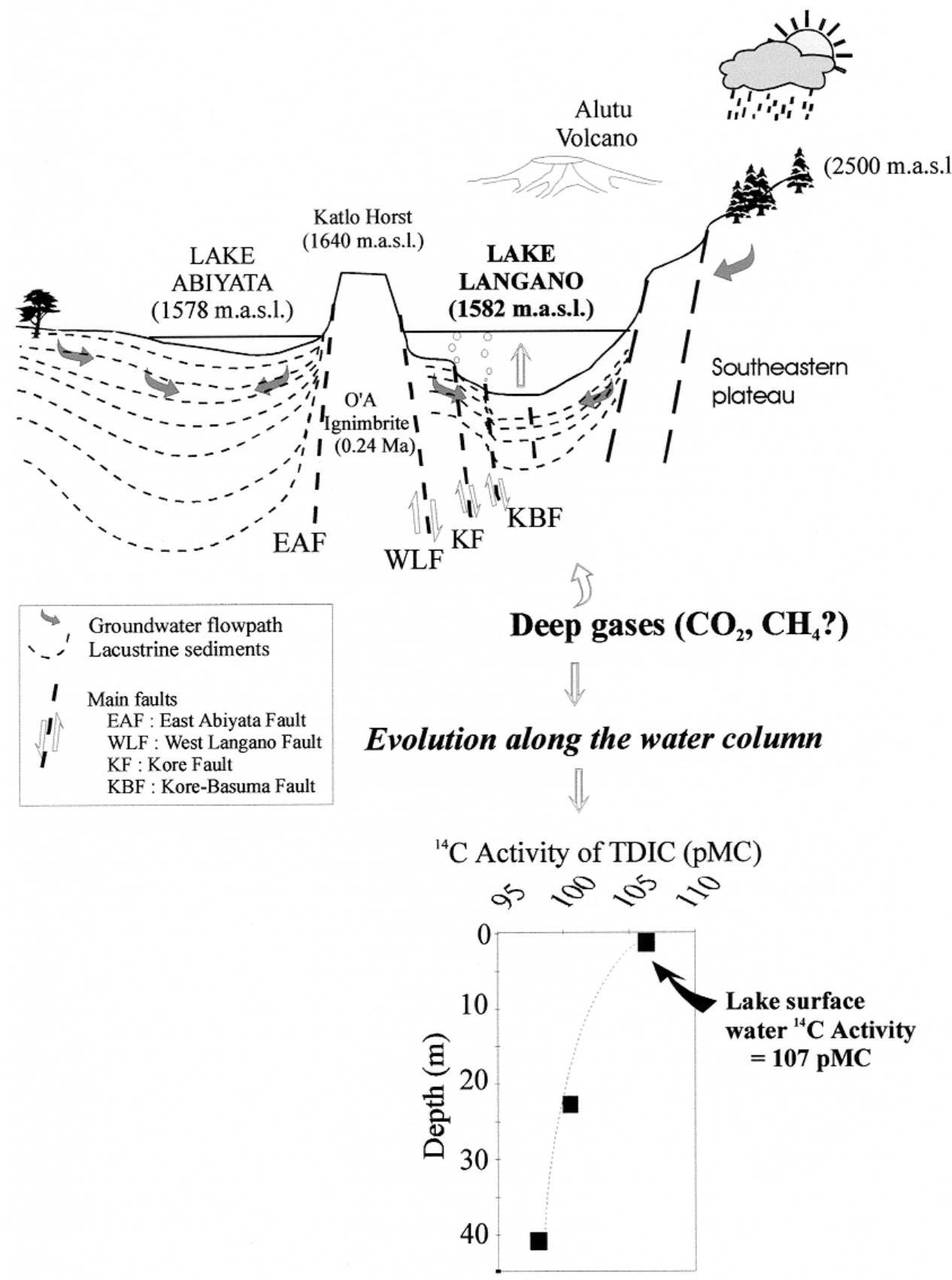

Figure 2 Schematic description of Lakes Abiyata and Langano sub-basin, and associated ${ }^{14} \mathrm{C}$ evolution of the total dissolved inorganic carbon (TDIC) of Lake Langano water (see Table 2 and Figure 1 for sample locations) 
Four samples of soil gases were thus taken from three sites (Table 4 lists locations and results). The first three samples of soil gas were obtained at about $2 \mathrm{~km}$ from the active fault zone, respectively under natural vegetation and culture (site 8 , Table 4 ). Both have a ${ }^{13} \mathrm{C}$ content in agreement with the mean $\delta^{13} \mathrm{C}$ values of soil gas in sahelian vegetation zone, i.e., about $-14 \%$ vs. PDB. In contrast, the fourth gas sample taken at the southern end of the WLF escarpment shows an enriched $\delta^{13} \mathrm{C}$ value of $-1 \%$ vs. PDB (site 7, Table 4). Such an enrichment in ${ }^{13} \mathrm{C}$ could be produced by $\mathrm{CO}_{2}$ and/or $\mathrm{CH}_{4}$ gases, via two geochemical pathways because their fractionation factors are quite different (Bottinga 1969; Friedman and O'Neil 1977). However, if we consider that $\mathrm{CH}_{4}$ produced by organic matter degradation during burial will get a ${ }^{13} \mathrm{C}$ signature of about $-70 \%$ vs. $\mathrm{PDB}$, the mixing with atmospheric $\mathrm{CO}_{2}$ in soil producing a $\delta^{13} \mathrm{C}$ value of $-1 \%$ vs. $\mathrm{PDB}$ requires the soil- $\mathrm{CH}_{4}$ reservoir to be considered infinite with respect to the atmospheric reservoir $\left({ }^{13} \mathrm{C}\right.$ fractionation factor of $\mathrm{CO}_{2}-\mathrm{CH}_{4}$ : $\sim-70 \%$ at $20^{\circ} \mathrm{C}$ ). This is quite impossible in this arid, vegetation-free area. Moreover, because carbonate chemistry in hydrological systems is strongly influenced by deep $\mathrm{CO}_{2}$ (Scripps Institution of Oceanography 1977), we assume that this gas mainly consists of $\mathrm{CO}_{2}$. As a consequence, this feature will induce some complications 1) in the establishment of the lake carbon balance, and 2) in the interpretation of water residence time inferred from carbon chemistry and isotopic contents.

Table 2 Measured AMS- ${ }^{14} \mathrm{C}$ activities, associated $\delta^{13} \mathrm{C}$ values and in-situ measurements of surface water, groundwater, and thermal spring from the Lake Langano basin ${ }^{\text {a }}$

\begin{tabular}{|c|c|c|c|c|c|c|c|c|}
\hline Sample & Depth & $\begin{array}{c}\text { Analyses } \\
\text { nr } \\
\text { (Orsay) }\end{array}$ & $\begin{array}{c}{ }^{14} \mathrm{C} \text { activity } \\
\text { (pMC) }\end{array}$ & $\begin{array}{c}\text { Measured } \\
{ }^{14} \mathrm{C} \\
\text { age }(\mathrm{BP})\end{array}$ & $\begin{array}{c}\delta^{13} \mathrm{C} \\
\text { (\%o vs. } \\
\text { PDB) }\end{array}$ & $\mathrm{pH}$ & $\begin{array}{c}\mathrm{T} \\
\left({ }^{\circ} \mathrm{C}\right)\end{array}$ & $\begin{array}{c}\mathrm{EC} \\
\left(\mathrm{mS} \cdot \mathrm{cm}^{-1}\right)\end{array}$ \\
\hline \multirow[t]{3}{*}{ Lake water column } & Surface & H1207 & $107.1 \pm 0.9$ & & -1.76 & 21.2 & 9.2 & 1503 \\
\hline & $25 \mathrm{~m}$ & H1386 & $100.4 \pm 0.6$ & & & 21.6 & 9.2 & 1498 \\
\hline & $40 \mathrm{~m}$ & H1389 & $97.8 \pm 0.6$ & & & 21.4 & 9.1 & 1496 \\
\hline Geothermal spring & & H1381 & $4.8 \pm 5.1$ & & & n.d. & $>100$ & 2580 \\
\hline Horakelo River & Surface & H1209 & $112.0 \pm 0.8$ & Modern & -2.13 & 18.9 & 9.3 & 1845 \\
\hline Bekele Mola borehole & & & $40.8 \pm 0.6$ & & -3.62 & & & \\
\hline
\end{tabular}

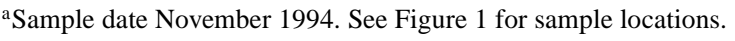

\section{The LL-III Core Sedimentary Sequence}

High-resolution reflection seismic data acquired in 1994 (Sparker profiles; Jeudy 1995; Le Turdu et al. 1999) combined with core data (Mohammed and Bonnefille 1991; Mohammed 1992) indicate that recent sedimentation in the central basin is characterized by homogeneous muds and organic oozes with a high gas content of biogenic or hydrothermal origin. The 14.70-m long LL-III sequence was cored under 15-m water depth, on the northern end of the western littoral plateau (Figure 1c) using the Equarift stationary piston corer.

Sediment lithology is represented in Figure 3 (Le Turdu et al. 1999) and is characterized as follows: 1) from 1470 to $\sim 1000 \mathrm{~cm}, 0.1$ - to 0.5 -m-thick beds of ungraded to normally graded sand or gravelly sand are bound by flat, non-erosive surfaces, or diffusely bounded. These sands are overlain, from base to top, by massive dark-brown, silty muds, by medium- to coarse-grained sand, and by massive to laminated muds, 2) from $1000 \mathrm{~cm}$ to the core top, deposits consist of an alternation of dark-brown to grey-green diatom-rich, massive silty-clayey muds and green, silty sands. Air-fall pyroclastic layers from $\sim 1$ to $3 \mathrm{~cm}$ thick are situated between 960 and $820 \mathrm{~cm}$ indicating recent explosive volcanic activity. Very homogeneous muds are found between 150 and $345 \mathrm{~cm}$, and from 580 to $730 \mathrm{~cm}$. The core top is marked by more thick pyroclastic layers $(532-537 \mathrm{~cm} ; 385-390 \mathrm{~cm} ; 348-352.5 \mathrm{~cm} ; 139-$ $150 \mathrm{~cm}$ ), interbedded with greyish homogeneous marls. 
Table 3 Chemical contents of some surface water and groundwater from Lake Langano basin

\begin{tabular}{|c|c|c|c|c|c|c|c|c|c|c|c|c|c|c|}
\hline Sample & Sampling & $\begin{array}{l}\text { TDS } \\
\text { Time }\end{array}$ & $\mathrm{pH}$ & $\begin{array}{c}\mathrm{Na}^{+} \\
\left(\mathrm{mg} \cdot \mathrm{L}^{-1}\right)\end{array}$ & $\underset{\left(\mathrm{mg} \cdot \mathrm{L}^{-1}\right)}{\mathrm{K}^{+}}$ & $\begin{array}{c}\mathrm{Ca}^{2+} \\
\left(\mathrm{mg} \cdot \mathrm{L}^{-1}\right)\end{array}$ & $\begin{array}{c}\mathrm{Mg}^{2+} \\
\left(\mathrm{mg} \cdot \mathrm{L}^{-1}\right)\end{array}$ & $\begin{array}{c}\mathrm{HCO}_{3}^{-} \\
\left(\mathrm{mg} \cdot \mathrm{L}^{-1}\right)\end{array}$ & $\begin{array}{c}\mathrm{CO}_{3}^{2-} \\
\left(\mathrm{mg} \cdot \mathrm{L}^{-1}\right)\end{array}$ & $\underset{\left(\mathrm{mg} \cdot \mathrm{L}^{-1}\right)}{\mathrm{Cl}^{-}}$ & $\underset{\left(\mathrm{mg} \cdot \mathrm{L}^{-1}\right)}{\mathrm{SO}_{4}^{2-}}$ & $\underset{\left(\mathrm{mg} \cdot \mathrm{L}^{-1}\right)}{\mathrm{F}}$ & $\underset{\left(\mathrm{mg} \cdot \mathrm{L}^{-1}\right)}{\mathrm{Br}}$ & $\underset{\left(\mathrm{mg} \cdot \mathrm{L}^{-1}\right.}{\mathrm{NO}_{3}}$ \\
\hline \multicolumn{15}{|l|}{ LAKE LANGANO } \\
\hline Lake surface $(\boldsymbol{l})$ & 1995 & & 9.2 & 361 & 34 & 4.6 & 6.5 & 649 & 72 & 151.0 & 11.2 & 14.0 & & \\
\hline Shebelle (L. suface) (2) & 1994 & 1346 & 9.2 & 386 & 28 & 4.5 & 0.8 & 622 & 72 & 214.0 & 18.3 & 0.0 & 0.65 & 0.00 \\
\hline Bekele Mola (L. suface) (3) & 3) 1994 & & 9.2 & 361 & 34 & 4.6 & 6.5 & 649 & 72 & 151.0 & 11.2 & 14.0 & & \\
\hline Island (L. surface) (4) & 1994 & 1335 & 9.2 & 375 & 28 & 4.3 & 6.7 & 665 & 72 & 156.4 & 11.4 & 14.9 & 0.60 & 0.15 \\
\hline \multicolumn{15}{|l|}{ Along the water column (5) } \\
\hline Fault (L. surface) & 1994 & 1425 & 9.2 & 398 & 28 & 4.67 & 6.27 & 736 & 72 & 151.9 & 11.9 & 14.2 & 0.59 & 0.61 \\
\hline Fault (10 m depth) & 1994 & 1524 & 9.2 & 426 & 28 & 4.37 & 6.38 & 810 & 72 & 150.5 & 11.5 & 14.5 & 0.59 & 0.11 \\
\hline Fault (25 m depth) & 1994 & 1402 & & 392 & 28 & 4.90 & 6.45 & 720 & 72 & 151.3 & 11.7 & 14.6 & 0.59 & 0.53 \\
\hline Fault (40 m depth) & 1994 & 1382 & 9.2 & 386 & 28 & 5.66 & 6.78 & 704 & 72 & 151.4 & 12.2 & 14.6 & 0.59 & 0.51 \\
\hline
\end{tabular}

With sites located as follows :

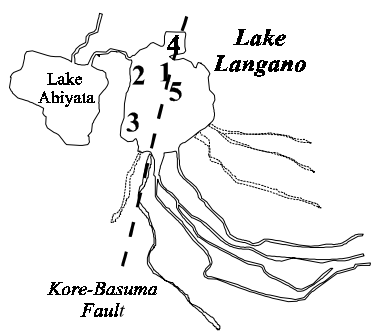

Table 4 Measured AMS- ${ }^{14} \mathrm{C}$ activities and associated $\delta^{13} \mathrm{C}$ values of modern vegetation and soil gases from Lake Langano basin

\begin{tabular}{cccc}
\hline \multicolumn{1}{c}{ Type* } & $\begin{array}{c}\text { Analyse } \mathrm{Nr} \\
\text { (Orsay) }\end{array}$ & $\begin{array}{c}{ }^{14} \mathrm{C} \text { Activity } \\
(\mathrm{pMC})\end{array}$ & $\begin{array}{c}\delta^{13} \mathrm{C} \\
(\% \text { vs PDB })\end{array}$ \\
\hline $\begin{array}{c}\text { Modern plants } \\
\text { Wood (6) }\end{array}$ & $\mathrm{H} 1785$ & $109.0 \pm 0.6$ & -23.1 \\
Wood (6) & $\mathrm{H} 1787$ & $109.9 \pm 0.7$ & -23.8 \\
Soil Gases under: & & \\
$\begin{array}{c}\text { Natural vegetation-Fault zone (7) } \\
\text { Natural vegetation (8) } \\
\text { Cultivated field (9) }\end{array}$ & & -1.2 \\
& & -13.0 \\
\hline
\end{tabular}

*, Samples taken from trees located nearby the southern bank/beach of Lake Langeno (see Figure 1 for sample location).

With sites located as follows :

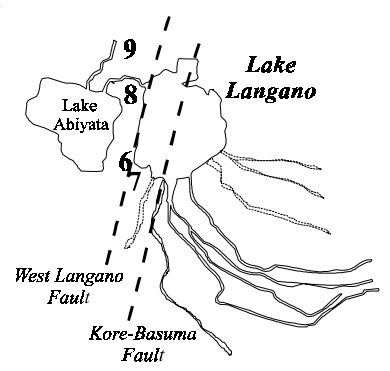




\section{Lake Langano Modern Hydrological System}

The modern hydrological and water geochemical balances were investigated first, to provide a reference system for lake water residence time and carbon recycling over the whole catchment (e.g. Travi et al. 1997; Chernet 1998).

\section{Hydrological Balance}

Lake Langano is an open lake with a mean surface of about $230 \mathrm{~km}^{2}$. Water inflow mainly comes from small, intermittent rivers that drain a catchment consisting mostly of ignimbrites and some acidic volcanic rocks, and reach the lake on its southern and southeastern shores (Figure 1). Waters entering the lake are sodium-carbonated-dominated such as $[\mathrm{Na}+\mathrm{K}]>[\mathrm{Ca}+\mathrm{Mg}]$ and $[\mathrm{Ca}+\mathrm{Mg}]$ $<\left[\mathrm{HCO}_{3}\right]$ (Table 3). The lake output is concentrated on the Horakelo River (long time-series of gauging data in Chernet 1998) that flows from the northeastern shore of the lake towards Lake Abiyata (Figure 1). For a maximum water level fluctuation of about $1 \mathrm{~m}$ registered between 1971 and 1994 (Chernet 1998), Lake Langano volume varied between 5400 and $5700 \mathrm{Mm}^{3}$.

Chemical models showed that the water mineralization is mainly influenced by the evaporative concentration process of a unique source of elements (silicate hydrolysis) producing $\mathrm{NaHCO}_{3}$ in water with high $\mathrm{pH}$ values (Table 3; Chernet 1998; Chernet, Travi and Valles 2001). This evaporative process is observed all over the basin and implies homogeneity of the water chemical characteristics at the basin scale. As a result, there is a relative stability of the $\mathrm{HCO}_{3}$ content (with respect to the present-day lake level), associated with very low calcium contents (Chernet 1998).

The mean residence time of Lake Langano water is calculated according to hydrological measurements conducted during the last 20 years, according the definition of Pourriot and Meybeck (1995) as follows:

$$
t=V / I \text { or } t=V / Q
$$

with $t=$ mean residence time; $V=$ lake volume; $I=$ total inputs, and $Q=$ total outputs.

Using a mean lake volume of $5550 \mathrm{Mm}^{3}$, a mean outflow value of about $120 \mathrm{Mm}^{3} \cdot \mathrm{yr}^{-1}$ as represented by the Horakelo River flows for the 1979-1994 period, and an evaporation rate close to 2 m. $\mathrm{yr}^{-1}$ (Chernet 1998; Vallet-Coulomb et al. 2000), the mean residence time of Lake Langano waters is estimated between 10 and 15 years.

Carbon balance: In the water balance, the "evaporation" term is dominant. However, dissolved carbon species (i.e. dissolved $\mathrm{CO}_{2}, \mathrm{HCO}_{3}-, \mathrm{CO}_{3}{ }^{2-}$ ) are not removed from the lake through evaporation. The carbon cycle and carbon residence time in Lake Langano water have to be considered. The estimation appears to be possible since there is a linear trend in carbonate concentrations in Lake Langano water during the evaporative concentration process (Chernet 1998). This implies both a very low rate of $\mathrm{CaCO}_{3}$ chemical precipitation and a relatively constant stock of carbon for the same lake level.

As demonstrated by a long time series of in-situ chemical and gauging measurements, the Horakelo River water presents the same carbon concentration as that of Lake Langano water, i.e. 600-700 mg.L $\mathrm{L}^{-1}$ (Chernet 1998). We thus can state that:

$$
t=V \times\left[C_{\text {Lake }}\right] / Q \times\left[C_{\text {River }}\right]=V / Q \sim 5550 / 120
$$

with $V=$ lake volume, $Q=$ total outputs (i.e. Horakelo River), and $\left[\mathrm{C}_{\text {Lake }}\right]$ and $\left[\mathrm{C}_{\text {River }}\right]=$ carbon concentrations of lake and river waters, respectively, giving a mean residence time of about 45 years. 
However, the relative hydrological steady state does not fully exclude carbonate precipitation as shown by the calcium content decrease. Moreover, the contribution of carbon brought to the lake by deep $\mathrm{CO}_{2}$ and its associated degassing at the lake surface are not taken into account. Assuming that deep $\mathrm{CO}_{2}$ production remains constant, these contributions might be important especially during lowstands. The value of 45 years is a maximum estimate and we can reasonably assert that the mean carbon residence time in Lake Langano would be between 10 and 30 years. The mean values of 15 and 20 years will thus be used below for the calculation and correction of the ${ }^{14} \mathrm{C}$ chronology of lacustrine deposits.

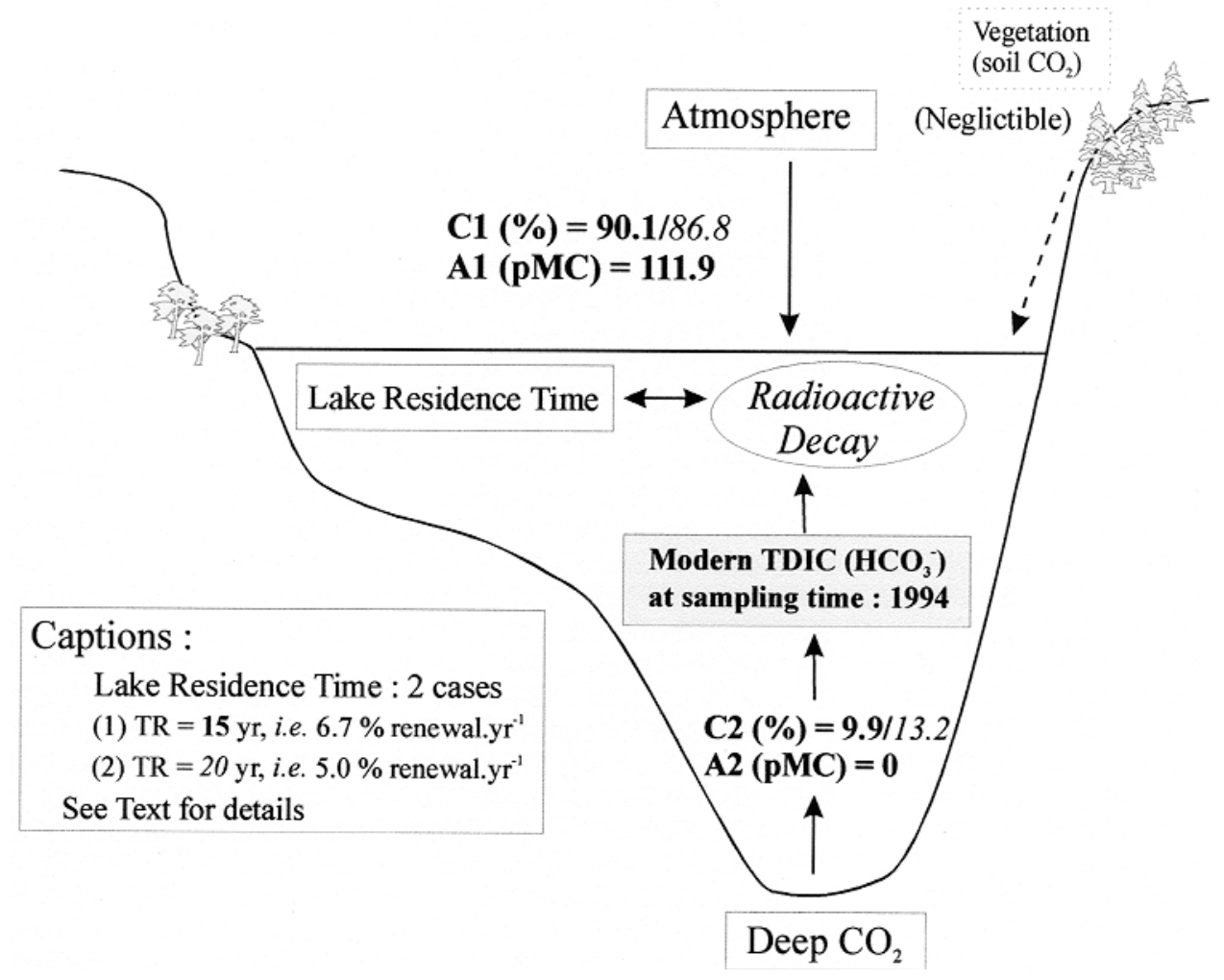

Figure 3 Representation of the 2-black box model used for ${ }^{14} \mathrm{C}$ datings correction

\section{Isotopic Contents of Modern Water}

Isotopic measurements ( ${ }^{13} \mathrm{C}$ content and ${ }^{14} \mathrm{C}$ activity) were performed on the TDIC of 1 ) samples from the water column at three depths: $40 \mathrm{~m}, 25 \mathrm{~m}$, and the lake surface, 2) the lake outflow, i.e. Horakelo River, and 3) the geothermal spring rising on the small Edo Laki Island at the northern end of the lake (North Bay) (Figure 1). Sample locations and analytical results are reported in Table 2.

The ${ }^{14} \mathrm{C}$ activity of the 40 -m deep water sample collected at about $2 \mathrm{~km}$ from the $\mathrm{KBF}$ is $97.8( \pm 0.6)$ $\mathrm{pMC}$, and confirmed the underwater geothermal activity. Phenomena of dispersion and diffusion of carbon within the water column are not sufficient to maintain the isotopic equilibrium between the TDIC and the atmospheric reservoir. At sampling time, the ${ }^{14} \mathrm{C}$ activity of surface water only is $107.1( \pm 0.9)$ pMC compared to the 111.9 pMC activity of atmospheric $\mathrm{CO}_{2}$ recorded in 1994 , and as measured on the Horakelo River sample where re-equilibration with the atmosphere is totally 
reached (i.e. $112.0( \pm 0.8)$ pMC; Figure 3; Table 2). Datings performed on phyto-planktonic organic matter and shells living in the surface lake water thus need to be corrected.

\section{RESULTS}

\section{AMS- ${ }^{14} \mathrm{C}$ Chronology of Lake Langano Core LL-III}

Authigenic materials are required for the establishment of the ${ }^{14} \mathrm{C}$ chronology and their selection has been based on microscopic observation of charcoal and macrophyte remains. Zones with an important detrital fraction or presenting gas bubbles, even rich in charcoal, have been eliminated. The chronology of Core LL-III is then based on $9 \mathrm{AMS}-{ }^{14} \mathrm{C}$ datings as performed on authigenic charcoal, total organic matter (TOM), and surface-living shells (Melanoides tuberculata; J C Plaziat, personal communication).

All the samples obtained by hand-picking directly after the core opening were subjected to the standard chemical protocol for AMS analyses 1) acid-alkali-acid chemical treatment for organic matter, and 2) cleaning with slightly acidic solution for biogenic carbonates. AMS- ${ }^{14} \mathrm{C}$ and associated ${ }^{13} \mathrm{C}$ analyses were conducted on aliquots prepared according to the AMS protocol: 1) organic material: burning at $860^{\circ} \mathrm{C}$ for $30 \mathrm{mn}$, under vacuum, in presence of a mixing of copper-(II)-oxide/copper(III)-oxide and silver thread, and 2) shells by $\mathrm{H}_{3} \mathrm{PO}_{4}$ destruction under vacuum overnight. The $\mathrm{CO}_{2}$ gas obtained was graphitized on powdered iron with hydrogen at $650{ }^{\circ} \mathrm{C}$ for $100 \mathrm{~min}$, and graphite was compressed in analytical plots. Aliquot of the $\mathrm{CO}_{2}$ gas was then used for stable isotope measurements and/or stored for ${ }^{14} \mathrm{C}$-dating duplicates. Graphite sources were prepared in Orsay (Laboratory of Hydrology and Isotope Geochemistry, Orsay, France), and counted by the accelerator mass spectrometer at Gif-sur-Yvette (Tandetron facility, France). Analytical uncertainties, including laboratory errors, are $\pm 0.1 \%$ o for $\delta^{13} \mathrm{C}$ and between 0.5 and $0.8 \mathrm{pMC}$ for ${ }^{14} \mathrm{C}$ activity. All the dates are converted to calendar ages according to the revised calibration program CALIB 4.0 (Stuiver et al. 1998; Table 1b, section C), considering the mean 15-yr residence time of lake water.

The interpretation of the datings are discussed within the framework of the internal consistency of the whole chronology as well as according to the hydrological and geochemical balances of the basin. All the ${ }^{14} \mathrm{C}$ datings performed are in agreement with the stratigraphy, except the two lowermost ages defined on biogenic carbonates. The ${ }^{14} \mathrm{C}$ discrepancies correspond to datings of originally aragonitic Melanoides tuberculata shells, i.e. 12,270 $( \pm 100) \mathrm{BP}$ and 11,360 $( \pm 110) \mathrm{BP}$, at 1048.0 and $1185.0 \mathrm{~cm}$ depth, respectively. Semi-quantitative analyses using X-ray diffractometry show that the deepest shell sample is still made of pure aragonite while the more fragile 1050 -cm sample presents $17 \%( \pm 1 \%)$ of secondary calcite (Table 4$)$. These two samples of the same species develop in shallow aquatic environments, and the recrystallization can only have happened during burial. Thus, a second correction has to be applied.

\section{Deep $\mathrm{CO}_{2}$ and Diagenetic Processes on the Carbon Content of Lake Langano Deposits-First ${ }^{14} \mathrm{C}$ Correction}

The first correction to be considered corresponds to the imbalance of carbon species with respect to normal geochemical conditions and carbon acquisition, in both soils and water.

\section{Deep $\mathrm{CO}_{2}$ influence processes on the initial carbon content of Lake Langano deposits}

A first source of ${ }^{14} \mathrm{C}$ aging of authigenic materials (such as charcoal and plant remains) corresponds to the influence and assimilation of ${ }^{14} \mathrm{C}$-free soil $\mathrm{CO}_{2}$ linked to active faults by living plants. Bruns and co-authors (1980) described the specific $\delta^{13} \mathrm{C} / \mathrm{A}^{14} \mathrm{C}$ evolution of organic 
materials exposed to ${ }^{14} \mathrm{C}$-free $\mathrm{CO}_{2}$ fluxes in geothermal contexts, and showed that higher plants can have apparent (older) ages due to the possible admixture and assimilation during photosynthesis of up to $16 \%$ of dead $\mathrm{CO}_{2}$. Two woody samples from modern vegetation (benches and leaves from Pinus/Acacias) were taken in 1995 and 1996 from trees located right on the WLF on Lake Langano Southern beach (point 7; Table 4). They present ${ }^{14} \mathrm{C}$ activities of $109.0( \pm 0.9)$ and $109.9( \pm 0.9) \mathrm{pMC}$, respectively, lower than that of the atmosphere at sampling time. Considering the fractionation equation as follows: $\Delta^{14} \mathrm{C}=2.3 \varepsilon^{13} \mathrm{C}$, with $\varepsilon$, the fractionation factor between ${ }^{13} \mathrm{C}$ and ${ }^{14} \mathrm{C}$ (Saliège and Fontes 1984), the maximum 3-pMC difference observed with the atmosphere corresponds to a ${ }^{13} \mathrm{C}$ variation of $16 \%$ vs. PDB. One can note that this is exactly what is observed between the mean $\delta^{13} \mathrm{C}$ value of the woody samples analyzed (i.e. $-23 \%$ o vs. PDB) and the ${ }^{13} \mathrm{C}$ content of the atmosphere (i.e. $-7 \%$ vs. PDB). For ${ }^{14} \mathrm{C}$ activities comprised between 20 and $60 \mathrm{pMC}$, a 3-pMC variation of the initial ${ }^{14} \mathrm{C}$ activity gives a maximum age discrepancy of only about 250 years. Moreover, the mixing of deep $\mathrm{CO}_{2}$ in soil gases is localized nearby the lake shores, and influences only a part of the vegetation of the catchment area. Such a phenomenon of apparent aging of plant debris via ${ }^{13} \mathrm{C}$-depleted soil gases does not have to be considered around Lake Langano.

\section{Geochemical evolution of the ${ }^{14} \mathrm{C}$ cycle in the lake}

Following the estimation of the lake water mean residence time, the above-mentioned apparent aging of $5.8 \mathrm{pMC}$ of the lake surface water integrates the ${ }^{14} \mathrm{C}$ produced by nuclear weapon tests in the atmosphere during the $1960 \mathrm{~s}$. Reconstructing the evolution curve of the natural ${ }^{14} \mathrm{C}$ activity in the lake will allow for 1) the establishment of the single influence of the deep $\mathrm{CO}_{2}$ on the initial TDIC ${ }^{14} \mathrm{C}$ content before the 1960s, and 2) the correction of AMS- ${ }^{14} \mathrm{C}$ datings for the authigenic materials along the lacustrine sequence. The calculation of the dead carbon proportion before the influence of the ${ }^{14} \mathrm{C}$ produced in the atmosphere by nuclear weapon tests and still present in the lake in 1994 is required to allow for the reconstruction of ${ }^{14} \mathrm{C}$ initial curves.

The system can be described with a two-box model (Figure 3).

$$
\mathrm{A}^{14} \mathrm{C}_{\text {TDIC of lake water }}=\left[\mathrm{C} 1 \times \sum_{(i=1 \text { to } i=n)} \mathrm{A}^{14} \mathrm{C}_{\text {Atmospheric CO2 }}\right]+\left[\mathrm{C} 2 \times \mathrm{A}^{14} \mathrm{C}_{\text {Deep CO2 }}\right]
$$

and

$$
\mathrm{C} 1+\mathrm{C} 2=100 \%
$$

with $i$, single considered year, $n$, mean residence time of lake water, $\mathrm{C} 1$, percentage of atmospheric $\mathrm{CO}_{2}$ dissolving in the lake per year (assumed as constant for each of the $n$ years), and $\mathrm{C} 2$, percentage of deep $\mathrm{CO}_{2}$ bubbling at the lake bottom per year (assumed as constant for each of the $n$ years).

The dead carbon proportion refers to the following conditions:

1. using equation (1);

2. considering no Suess effect (Suess 1955), which means a constant atmosphere activity during the pre-bomb period (100 pMC), and a pre-bomb year, i.e. 1950;

3. assuming that this deep $\mathrm{CO}_{2}$ is of crustal origin and thus, ${ }^{14} \mathrm{C}$-free $\left(\mathrm{A}^{14} \mathrm{C}_{\text {Deep CO2 }}=0 \mathrm{pMC}\right)$.

Equation (1) becomes:

$$
\mathrm{A}^{14} \mathrm{C}_{\text {TDIC of lake water }}=\mathrm{C} 1 \times \sum_{(i=1 \text { to } i=n)} \mathrm{A}^{14} \mathrm{C}_{\text {Atmospheric CO2 }}
$$

The atmospheric ${ }^{14} \mathrm{C}$ activity has been reconstructed using already published data (e.g. Rafter and Ferguson 1957; Levin et al. 1992, 1995; Levin and Kromer 1998; Nydal and Lovseth 1983; Genty and Massault 1999; Figure 4). 

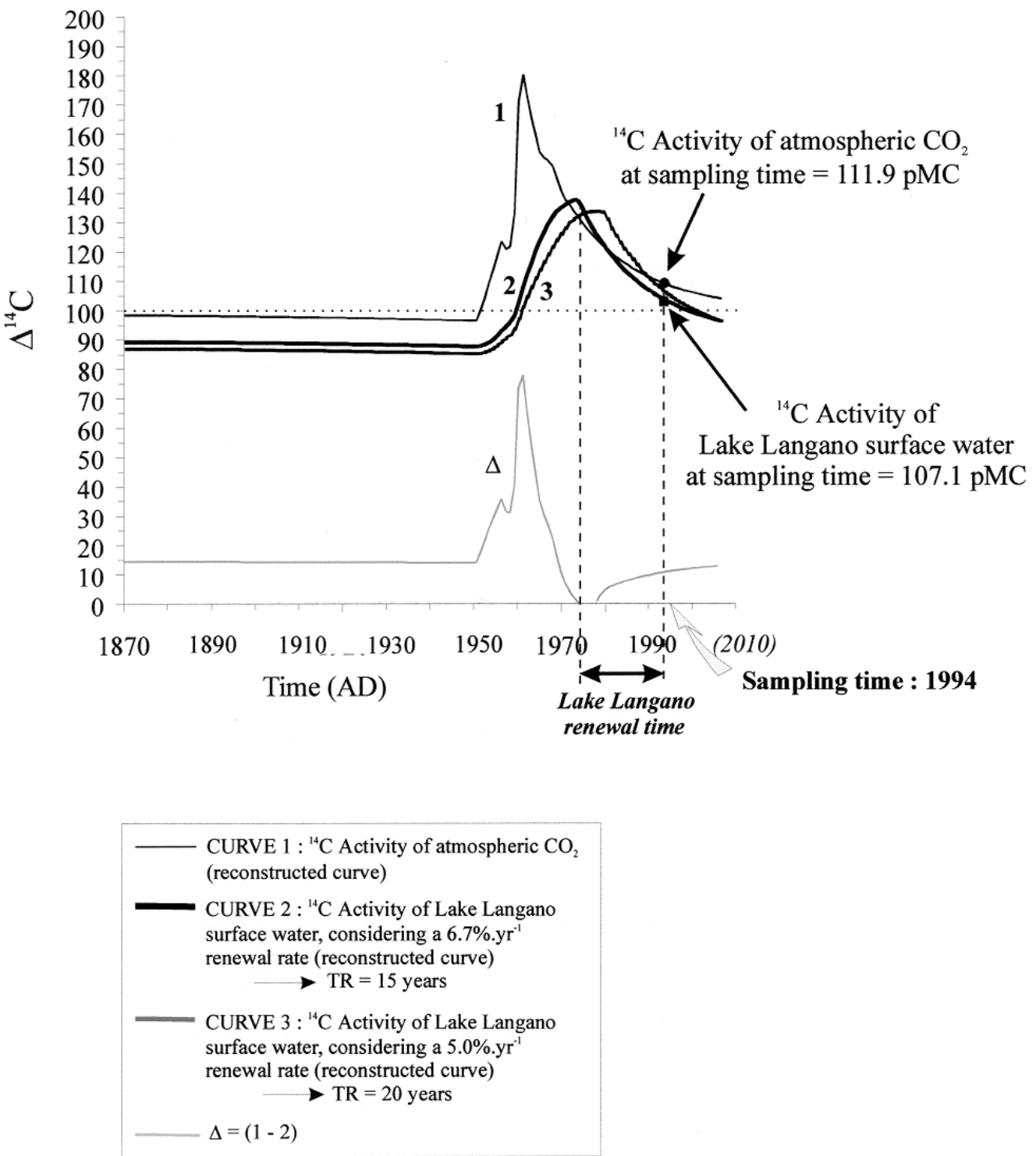

Figure 4 Comparison of the reconstructed ${ }^{14} \mathrm{C}$ activity of Lake Langano surface water with that of atmospheric $\mathrm{CO}_{2}$ (Curve 1; after Libby et al. 1949; Levin et al. 1980, 1992, 1995; Kromer and Becker 1993; Levin and Kromer 1998); two specific cases are considered: Curve 2 for a mean residence time of $15 \mathrm{yr}$, and Curve 3 for a mean residence time of $20 \mathrm{yr}$. 


\section{CORE LL-III}

Sedimentation description

Mud

Coarse sands and gravels Coarse to fine pyroclastites

Fine homogeneous mud Coarse to fine pyroclastites

Clay with Sands and gas bubbles

Fine homogeneous mud

Fine pyroclastic layers

Interstratification of mud sand and pyroclastites

Clay with gravels Fine homogeneous mud

Fine to coarse sands
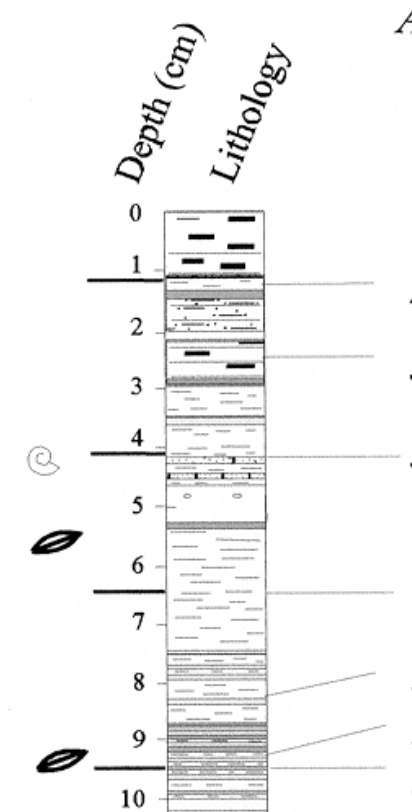

Measured

AMS $-{ }^{14} C$ Ages

(yr B.P.)
Calibrated corrected

${ }^{14} \mathrm{C}$ Ages

(cal. yr B.P.)

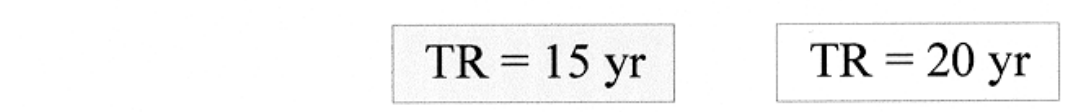

$4490 \pm 70 *$

5120

5120

$2 \div \quad 5670+100$

5600 5385

6800

6800

$7280 \pm 80^{+}$

7425

7250

$9460 \pm 100 *$

10690

10690

$9590 \pm 100 *$

10870

10870

11110

11110

$9640 \pm 80$

11400

11165

$12270 \pm 100^{s}$

12725

12330

Figure 5 Stratigraphic log of Lake Langano Core LL-III and associated measured and corrected ${ }^{14} \mathrm{C}$ chronologies (see text for calibration methods) 
In order to fit the measured ${ }^{14} \mathrm{C}$ activity of the lake water TDIC $(107.1( \pm 0.9)$ pMC) with the evolution of the atmospheric ${ }^{14} \mathrm{C}$ concentration (i.e. true $\mathrm{A}^{14} \mathrm{C}_{\mathrm{Atmospheric} \mathrm{CO} 2}$ in $1994=111.9 \mathrm{pMC}$ ), a stepby-step incrementation has been applied on parameter $\mathrm{C} 1$. This brought to the calculation of the respective parts of every end-member of the model:

- For a mean residence time (TR) of 15 years: $\mathrm{C} 1=9.9 \%$ and $\mathrm{C} 2=90.1 \%$;

- For a mean residence time (TR) of 20 years: $\mathrm{C} 1=13.2 \%$ and $\mathrm{C} 2=86.8 \%$.

Curves (2) and (3) have been reconstructed by extending the above-mentioned C1/C2 ratio to the past (Figure 4). The two scenarios of a 15-yr and a 20-yr residence time show differences of respectively 9.32 and $12.42 \mathrm{pMC}$ before the $1960 \mathrm{~s}$ between the atmospheric ${ }^{14} \mathrm{C}$ concentration and the lake TDIC.

Despite the fact that the TDIC activity of lake surface waters has obviously fluctuated through time in response to lake level variation, the ${ }^{14} \mathrm{C}$ diffusion rate in the lake water column must be considered unchanged at the sampling site and within the period reached in core LL-III. Indeed, this proposition is likely correct when Lake Langano is disconnected from the three other lakes of the basin, since its level is controlled by the Horakelo River. However, the hypothesis of an unchanged deep- ${ }^{14} \mathrm{C}$ production at the lake bottom and diffusion rate in the water column (due to increasing dilution processes?) becomes unpredictable during phases of lacustrine highstands.

Deep $\mathrm{CO}_{2}$ and Diagenetical Influence Processes on the Carbon Content of Lake Langano Deposits-Second ${ }^{14} \mathrm{C}$ Correction (Diagenetical Processes on Biogenic Carbonates)

As described above (\# Isotopic contents), the post-sedimentary recrystallization of the 1048-cm shell is likely due to preferential interstitial water circulations, assuming that this interstitial water has a ${ }^{14} \mathrm{C}$-free TDIC due to deep $\mathrm{CO}_{2}$ partial dissolution while rising. Since the first correction to be applied on this shell sample corresponds to the surface water TDIC aging (Table 1b, section A), the second correction varies according to the mean residence time of the lake water (Table 1B, section B). The correction is based on a simple mass balance model, as follows:

$$
A^{14} \mathrm{C}_{\text {recrystallized shell }}=\mathrm{LN}(2) / T \times \operatorname{LN}\left[\left(\left(A_{\text {o [corrected }]} \times 0.17 / 100\right)+A_{\text {o [corrected }]}\right) / A\right]
$$

with $T=$ half-life of ${ }^{14} \mathrm{C}, A_{\mathrm{o} \text { [corrected] }}=$ initial ${ }^{14} \mathrm{C}$ activity of the sample after correction from the lake surface water apparent aging, and $A=$ measured ${ }^{14} \mathrm{C}$ activity of the sample.

For a mean residence time of $15 \mathrm{yr}$, the two-step correction of the 1048-cm depth shell gives a minimum age of $9990( \pm 100) \mathrm{BP}(11,400$ cal BP; Table 1$)$.

\section{DISCUSSION AND CONCLUSION}

1. The successive geochemical corrections applied on ${ }^{14} \mathrm{C}$ datings performed on Lake Langano sediments are based on the establishment of the hydrological and chemical balances of the lake, considering a 15-yr residence time for the lake water, and taking into account both the nuclearinduced ${ }^{14} \mathrm{C}$ in the atmosphere and the deep ${ }^{14} \mathrm{C}$-dead $\mathrm{CO}_{2}$ production rising along active faults at the lake bottom. This allows for the definition of a reliable ${ }^{14} \mathrm{C}$ chronology along Core LLIII (Table1). The corrected ${ }^{14} \mathrm{C}$ time-scale indicates that Lake Langano sediments have registered the Late Pleistocene and Holocene periods, with a global mean sedimentation rate (msr) of $1.12 \mathrm{~m} \cdot \mathrm{ka}^{-1}$.

2. The inflection points defined with the msr curve are obviously linked to the specific sedimentary levels dated due to the few datable materials available in Core LL-III. Nevertheless, these msr fluctuations are important and relatively well-correlated with the lithostratigraphy (Figure 5). 


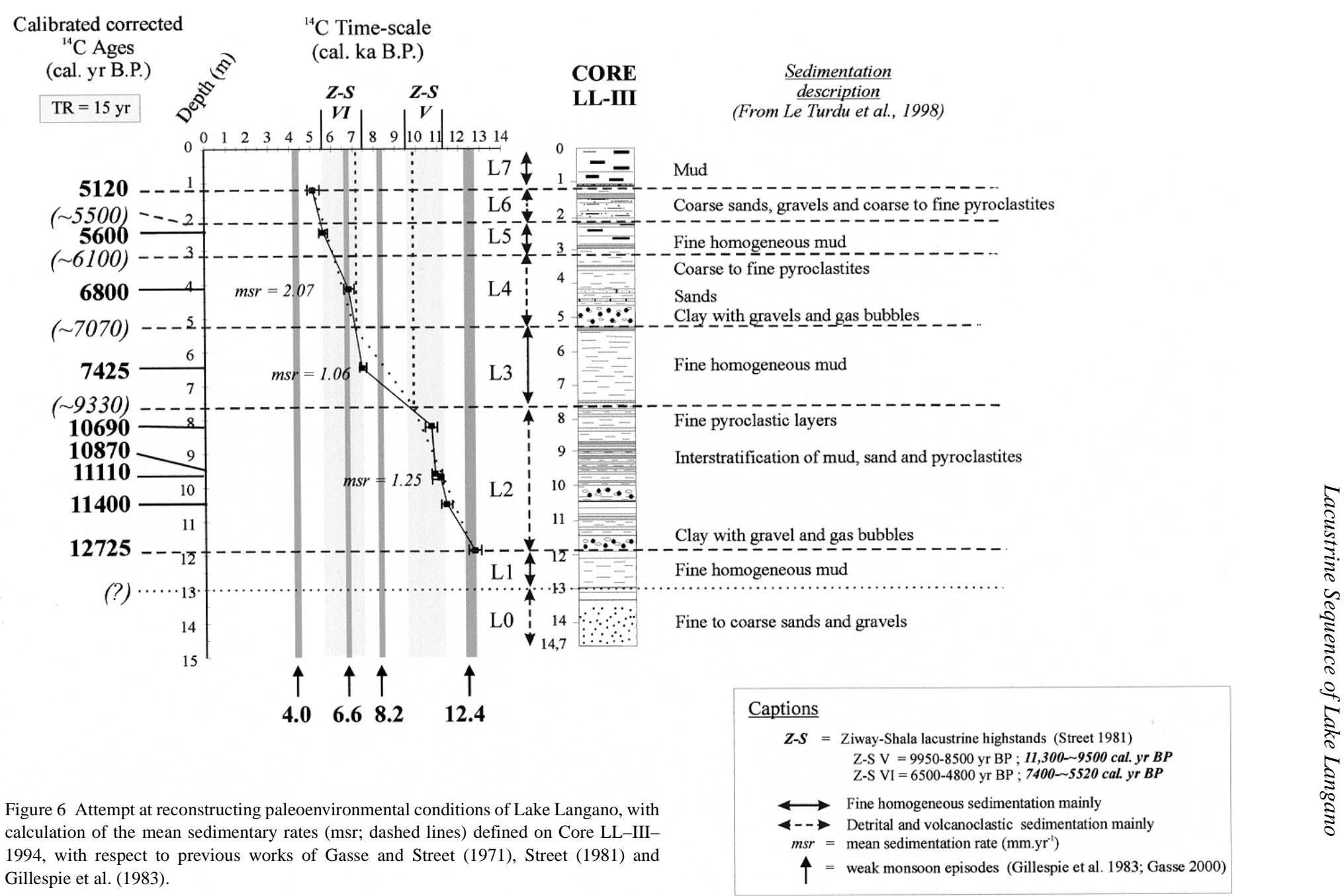


3. The comparison between the specific sedimentation facies (Le Turdu et al. 1999) and the AMS${ }^{14} \mathrm{C}$ dates allows for the distinction of several major phases along core LL-III from base to top (Figure 6). These seven intervals, i.e. from L0 to L6, respectively, are not all marked by ${ }^{14} \mathrm{C}$ dated levels and most of them have been calendar- ${ }^{14} \mathrm{C}$ dated (in italics and brackets in Figure 6; see Table 1) by extrapolation between measured levels and seem to be relevant to deduce the paleoenvironmental history of Lake Langano with respect to previous works of Gasse and Street (1971) and Street (1981):

- Phases LO (14.70-13.00m depth) and L1 (13.00-12.72 m depth) at the very core base are characterized by a drastic difference in sedimentation: zone L0 (coarse sands and gravels) could be likely related to the crater rim erosion;

- Phase L2 (12.72-7.60 m depth; 12,725- 9330 cal BP) is mainly detrital-deposited (fine to coarse sands, gravels and pyroclatites), and is characterized by a high sedimentation rate of $1.25 \mathrm{~mm} \cdot \mathrm{yr}^{-1}$;

- Although based on the stratigraphic description of Le Turdu and co-authors (1999) and only one single ${ }^{14} \mathrm{C}$ age, Phase L3 is comprised between 7.60 and $\sim 5.25 \mathrm{~m}$ depth $(\sim 9330-\sim 7070$ cal BP), and consists exclusively of finely homogeneous muds with a low msr, i.e. $1.06 \mathrm{~mm}^{-\mathrm{yr}^{-1}}$; this sedimentation may reflect a calm deposition medium, with some shell development (Le Turdu et al. 1999);

- Phase L4 ( 7070- 6100 cal BP) begins at $~ 5.25 \mathrm{~m}$ depth, and extends up to $3.15 \mathrm{~m}$ depth (core top); this interval is characterized by a high deposition rate, the increase in msr having been already began at the top of the L3 interval (mean msr $=\sim 2.07 \mathrm{~mm} \mathrm{yr}^{-1}$ );

- Phase L5 is defined between 3.15 and $2.10 \mathrm{~m}$ depth ( 6100- 5500 cal BP) and consists on a high detrital fraction, except a small event of fine homogeneous mud between 2.9 and $~ 2.3 \mathrm{~m}$ depth;

- Phase L6 is comprised between $\sim 2.30$ and $1.25 \mathrm{~m}$ depth ( 5500-5120 cal BP) and consists mainly in coarse sands, gravels and pyroclatites;

- Chronological uncertainty, due to coring problems and any corresponding ${ }^{14} \mathrm{C}$ dates, remains for the core top (i.e. Phase L7) which corresponds to a very fine, smooth sedimentation.

4. At first glance, Lake Langano seems to react relatively in agreement with the lacustrine highstands previously determined by Street in 1981. The fluctuations of the lake level are marked by an important increase in the sedimentation rate occurring at the beginning of those highstands, e.g. especially for the Z-S VI stage (Z-S V: 11,300- 9500 cal BP, and Z-S VI: 74005520 cal BP, respectively; Figure 6). No clear links appear between the sedimentation/ $/{ }^{14} \mathrm{C}$ time scale and the arid phases defined by Gillespie et al. (1983) at 12.4, 8.2, 6.6, and 4.0 cal ka BP (Figure 6). The $8.2 \mathrm{cal} \mathrm{ka} \mathrm{BP} \mathrm{event} \mathrm{falls} \mathrm{into} \mathrm{the} \mathrm{Lake} \mathrm{Langano} \mathrm{L3} \mathrm{interval} \mathrm{characterized} \mathrm{by} \mathrm{a}$ rather low msr.

5. In conclusion, Lake Langano can be "summarized" in three major phases, i.e. the L2, L3, and L4-to-L6 intervals. As demonstrated, the Ziway-Shala high lake levels agree with the lithostratigraphy and the chronology. However, a decrease in msr during lacustrine highstands is generally admitted due to the decrease in river inputs, and/or to minor erosional processes on the catchment area that allow for 1) the core site to be far from the lake shores, and 2) the detrital particles to be filtered by the development of a vegetation belt. Nevertheless, the geomorphology of the Ziway-Shala basin likely induced a low "lake surface increase/surface detrital input" ratio due to the presence of the eastern plateau and relief of the Ethiopian Rift to the east (Street 1981; Le Turdu et al. 1999). In fact, the site of Lake Langano Core LL-III could have been localized not too far from the river and the Rift-slope depositional areas. Further studies involving other environmental indicators (e.g. pollen and diatoms) will allow for discussion and improved accuracy of the chronology and associated paleoenvironmental phases through cross-checking of sedimentary rates and lake level variations, taking into account other major factors such as volcanism and tectonics. 


\section{REFERENCES}

Bonnefille R, Robert C, Delibrias G, Elenga C, Herbin, JP, Lézine AM, Perinet G, Tiercelin J-J, 1986. Palaeoenvironment of Lake Abijata, Ethiopia, during the past 2000 years. In: Frostick LE, Reid I, Renaut RW, Tiercelin J-J, editors. Sedimentation in African rifts. Geological Society of London, Spec. Publ. 25:25365.

Bottinga Y. 1969. Calculated fractionation factors for carbon and hydrogen isotope exchange in the system calcite- $\mathrm{CO}_{2}$-graphite-methane-hydrogen and water vapor. Geochemica Cosmochemica Acta 33:49-64.

Bruns M, Levin I, Munnich KO, Hubbertein HW, Filipakis S. 1980. Regional sources of volcanic carbon dioxide and their influence on ${ }^{14} \mathrm{C}$ content of present-day plant material. Radiocarbon 22(2):532-6.

Chernet T. 1982. Hydrogeology of the Lakes Region, Ethiopia. In: Ethiopian Institute of Geological Surveys, editors. Ministry of Mines and Energy. Mem. 7: $97 \mathrm{p}$.

Chernet T. 1998. Etude des méchanismes de minéralisation en fluorure et éléments associés de la région des lacs du Rift Ethiopien. Thèse de Doctorat. Université d'Avignon. 203 p. In French.

Chernet T, Travi Y, Valles V. 2001. Mechanism of degradation of the quality of natural water in the Lakes Region of the Ethiopian Rift Valley. Water Research 35(12):2819-32.

Colman SM, Jones GA, Rubin M, King JW, Peck JA, Orem WH, 1996. AMS radiocarbon analyses from Lake Baïkal, Siberia: challenges of dating sediments from a large, oligotrophic lake. Quaternary Geochronology (Quaternary Science Review) 15.

Fontes J-Ch, Gasse F. 1991 PALHYDAF (PALaeoHYdrology in AFrica: objectives, methods and major results). Palaeogeography, Palaeoclimatology, Palaeoecology 84:191-215.

Fontes J-Ch, Mélières F, Gibert E, Liu Qing, Gasse F. 1993. Stable isotope and radiocarbon balances of two tibetan lakes (Sumxi Co and Longmu Co) from 13,000 yr BP Quaternary Science Review 12:875-87.

Fontes J-Ch, Gasse F, Gibert E. 1996. Holocene environmental changes in Bangong basin (western Tibet). Part 1: modern setting, mineralogy, stable isotope of carbonates and radiometric chronology. Palaeogeography, Palaeoclimatology, Palaeoecology 120:25-47.

Friedman I, O'Niel JR. 1977. Compilation of stable isotopic fractionation factors of geochemical interest. In: Data of geochemistry. 6th edition. U.S. Geological Survey Publisher. Professional Paper, 440 KK. 106 p.

Gasse F, Street FA. 1978. Late Quaternary lake-level fluctuations and environments of the northern Rift Valley and Afar region (Ethiopia and Djibouti). Palaeogeography, Palaeoclimatology, Palaeoecology 25:145-50.

Gasse F, Arnold M, Fontes J-Ch, Fort M, Gibert E, Huc A, Yuanfang L, Liu Q, Melieres F, Van Campo E,
Fubao W, Qingsong Z. 1990. A 13,000 yr climatic record from western Tibet (Xizang, China). Nature 353:742-5.

Gasse F. 2000. Hydrological changes in the African tropics since the Last Glacial Maximum. Quaternary Science Review 19:189-211.

Genty D, Massault M. 1997. Bomb ${ }^{14} \mathrm{C}$ recoreded in laminated speleothems: dead carbon proportion calculation. Radiocarbon 39(1):33-48.

Genty D, Massault M. 1999. Carbon transfer dynamics from bomb- ${ }^{14} \mathrm{C}$ and $\delta^{13} \mathrm{C}$ time series of a laminated stalagmite from SW France - modelling and comparison with other stalagmite records. Geochimica Cosmochimica Acta 63(10):1537-48.

Geyh MA, Schotterer U, Grosjean M. 1998. Temporal changes of the ${ }^{14} \mathrm{C}$ reservoir effect in lakes. Radiocarbon 40(2):921-31.

Gibert E, Travi Y, Massault M, Chernet T, Barbecot F, Laggoun-Defarge F. 1999. Comparison between carbonate and organic AMS ${ }^{14} \mathrm{C}$ ages in Lake Abiyata sediments (Ethiopia): hydrochemistry and palaeoenvironmental implications. Radiocarbon 41(3):251-66.

Gillespie R, Street-Perrott FA, Switsur R. 1983. Postglacial arid episodes in Ethiopia have implications for climate prediction. Nature 306:680-3.

Jeudy V. 1995. Approche morphostructurale et sédimentaire du bassin du lac Langano, Rift Ethiopien, pour le Pléistocène supérieur. Projet ERICA. DEA, Université de Bretagne Occidentale.

Johnson TC. 1996. Sedimentary processes and signals of past climatic change in the large lakes of the East African Rift Valley. In: Johnson TC, Odada E, editors. The limnology, climatology and paleoclimatology of the east African lakes. Amsterdam: Gordon and Breach. p 367-412.

Kromer B, Becker B. 1993. German oak and pine ${ }^{14} \mathrm{C}$ calibration, 7200-9439 BC. Radiocarbon 35(1):125-35.

Le Turdu C, Tiercelin J-J, Gibert E, Travi Y, Lezzar KE, Richert J-P, Massault M, Gasse F, Bonnefille R, Decobert M, Gensous B, Jeudy V, Endale T, Umer M, Martens K, Atnafu B, Chernet T, Williamson D, Taïeb M. 1999. The Ziway-Shala lake basin system, Main Ethiopian Rift: influence of volcanism, tectonics and climatic forcing on basin formation and sedimentation. Palaeogeography, Palaeoclimatology, Palaeoecology 150:135-77.

Levin I, Bošsinger R, Bonani G, Francey RJ, Kromer B, Munnich KO, Suter M, Trivett NBA, Wölfi W. 1992. Radiocarbon in atmospheric carbon dioxide and methane: global distribution and trends. In: Taylor RE, Long A, Kra RS, editors. Radiocarbon after four decades. New York: Springer-Verlag. p 503-18.

Levin I, Graul R, Trivett NBA. 1995. Long-term observations of atmospheric $\mathrm{CO}_{2}$ and carbon isotopes at continental sites in Germany. Tellus 47B:23-34.

Levin I, Kromer B. 1998. Twenty years of high precision 
atmospheric ${ }^{14} \mathrm{CO}_{2}$ observations at Schauinsland station, Germany. Radiocarbon 39(2):205-18.

Libby WF, Anderson EC, Arnold JR. 1949. Age determination by radiocarbon content: world-wide assay of natural radiocarbon. Science 109:227-8.

Mohammed MU. 1992. Paléoenvironnement et paléoclimatologie des derniers millénaires en Ethiopie. Contribution palynologique. Thèse de Doctorat, Université d'Aix-Marseille III. 219 p. In French.

Mohammed MU, Bonnefille R. 1991. The recent history of vegetation and climate around lake Langano (Ethiopia). Palaeoecology of Africa 22:267-80.

Nydal R, Losveth K. 1983. Tracing bomb ${ }^{14} \mathrm{C}$ in the atmosphere 1962-1980. Journal of Geophys. Research $88: 3621-42$.

Pourriot R, Meybeck M. 1995. Limnologie générale. Eds Masson, Paris (France). 956 p.

Rafter TA, Fergusson GJ. 1957. Atom bomb effect - recent increase of Carbon-14 content of the atmosphere and biosphere. Science 126:557-8.

Rozanski K, Araguas-Araguas L, Gonfiantini R. 1996. Isotope patterns of precipitation in the east African region. In: Johnson TC, Odada E, editors. The limnology, climatology and paleoclimatology of the east African lakes. The Netherlands: Gordon and Breach. $\mathrm{p}$ 79-93.

Saliège JF, Fontes J-Ch. 1984. Essai de détermination expérimentale du fractionnement des isotopes ${ }^{13} \mathrm{C}$ et ${ }^{14} \mathrm{C}$ du carbone au cours de processus naturels. International Journal of Applied Radiation and Isotopes 35(1):55-62.

Street FA. 1981. Chronology of late Pleistocene and Ho- locene lake-level fluctuations, Ziway-Shala Basin, Ethiopia. In: Leakey RE, Ogot BA, editors. Proceedings of the 8th Panafrican Congress of Prehistory and Quaternary Studies. 5-10 Sept 1977. Nairobi, Kenya. p 143-6.

Stuiver M, Reimer PJ, Bard E, Beck JW, Burr GS, Hughen KA, Kromer B, McCormac G, van der Plicht J, Spurk M. 1998. INTCAL98 radiocarbon age calibration, 24,000-0 cal BP. Radiocarbon 40(3):104183.

Scripps Institution of Oceanography. 1977. Isotopic geochemistry and hydrology of geothermal water in the Ethiopian Rift valley. Isotope Laboratory, University of California, SIO Reference 77-14. 140 p.

Suess HE. 1955. Radiocarbon concentration in modern wood. Science 122:415-7.

Travi Y, Chernet T, Gibert E. 1997. Study of hydrological behaviour of the Lake Region in the Ethiopian Rift, using hydrological, hydrochemical and isotopic data: palaeohydrological implications. Colloque "Volcanisme, Rifting et Paléoclimats dans le Rift Ethiopien et la Dépression de l'Afar". Addis-Abeba, Ethiopia. p 36.

Vallet-Coulomb C, Legesse D, Gasse F, Travi Y, Chernet T. 2000. Lake evaporation estimates in tropical Africa from limited meteorological data. Journal of Hydrology 245:1-18.

WMO/IAEA/GNIP Network. 1998. Statistical treatment of data on environmental isotopes in precipitation. In: IAEA (Vienna, Austria)/WMO, editors. World survey of global network for isotopes in precipitation. Nr 311. 